\title{
Correction: Differentiation of quantitative CT imaging phenotypes in asthma versus COPD
}

Choi S, Haghighi B, Choi J, et al. Differentiation of quantitative CT imaging phenotypes in asthma versus COPD. BMJ Open Resp Res 2017;4:e000252. doi:10.1136/bmjresp-2017-000252.

The author's name, Kazeroni EA, has been corrected to Kazerooni EA.

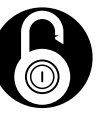

\section{OPEN ACCESS}

Open Access This is an Open Access article distributed in accordance with the terms of the Creative Commons Attribution (CC BY 4.0) license, which permits others to distribute, remix, adapt and build upon this work, for commercial use, provided the original work is properly cited. See: http://creativecommons.org/licenses/by/4.0/

(c) Article author(s) (or their employer(s) unless otherwise stated in the text of the article) 2018. All rights reserved. No commercial use is permitted unless otherwise expressly granted.

BMJ Open Resp Res 2018;5:e000252corr1. doi:10.1136/bmjresp-2017-000252corr1

A) Check for updates 